\title{
Impact of Wheat streak mosaic virus and Triticum mosaic virus Coinfection of Wheat on Transmission Rates by Wheat Curl Mites
}

C. Oliveira-Hofman, Department of Entomology; S. N. Wegulo, Department of Plant Pathology; S. Tatineni, United States Department of Agriculture-Agricultural Research Service and Department of Plant Pathology; and G. L. Hein, Department of Entomology, University of Nebraska-Lincoln University of Nebraska-Lincoln, Lincoln 68583

\begin{abstract}
Oliveira-Hofman, C., Wegulo, S. N., Tatineni, S., and Hein, G. L. 2015. Impact of Wheat streak mosaic virus and Triticum mosaic virus coinfection of wheat on transmission rates by wheat curl mites. Plant Dis. 99:1170-1174.

Wheat streak mosaic virus (WSMV) and Triticum mosaic virus (TriMV) are transmitted by the wheat curl mite (WCM, Aceria tosichella), and coinfections of wheat by these viruses are common in the field. Previous work has shown that mite genotypes vary in their ability to transmit TriMV. However, the degree to which coinfection of wheat modifies WCM vector competence has not been studied. The objective was to determine whether mite genotypes differed in virus transmission ability when feeding on wheat coinfected by WSMV and TriMV. First, WCM genotype type 2 was used to determine virus transmission rates from mock-, WSMV-, TriMV-, and coinfected wheat plants. Transmission rates were determined by using single-mite transfers from replicated source plants. Coinfection reduced WSMV transmission by type 2

WCM from 50 to $35.6 \%$; however, coinfection increased TriMV transmission from 43.3 to $56.8 \%$. Mite survival on single-mite transfer test plants indicates that the reduction in WSMV transmission may result from poor mite survival when TriMV is present. In a second study, two separate colonies of WCM genotype type 1 were tested to assess the impact of coinfection on transmission. Type 1 mites did not transmit TriMV from coinfected plants but the two colonies varied in transmission rates for WSMV (20.9 to 36.5\%). Even though these changes in mite transmission rates are moderate, they help explain the high relative incidence of TriMV-positive plants that are coinfected with WSMV in field observations. These findings begin to demonstrate the complicated interactions found in this mite-virus complex.
\end{abstract}

The wheat curl mite (WCM, Aceria tosichella Keifer) is the only known vector of Wheat streak mosaic virus (WSMV, genus Tritimovirus, family Potyviridae), Wheat mosaic virus (WMoV, also known as High Plains virus; tentative member of the genus Emaravirus) and Triticum mosaic virus (TriMV, genus Poacevirus, family Potyviridae) $(15,16,21,25)$. These viruses are widespread across the Great Plains of the United States and cause significant yield losses to wheat in the region $(2-4,26)$. Kansas's disease reports estimate that the average annual loss due to the WCM-vectored virus complex was $1 \%$ through the past 20 years (1); however, severely affected fields often have $100 \%$ yield loss. In field surveys, WSMV is the most prevalent of these viruses, followed by WMoV and TriMV $(2,3)$. Triple infection by the viruses can occur at low rates, but co-infections are more common (2,3). Single infections in the field are most likely to be WSMV. TriMV infections appear to be dependent on WSMV because $91 \%$ of TriMV-positive samples were coinfected with WSMV (3). WSMV and TriMV exhibit synergism when they coinfect wheat through increased titers of both viruses, greater symptom expression, and increased yield loss $(4,23)$.

Field populations of WCM are made up of different biotypes, strains, and genotypes. Biotypic differences in WCM response to resistant wheat lines have been observed (7-9). Host-specific strains of the WCM were shown when mites reared on various grass hosts could not survive on wheat and vice versa (20). Mites reared on western wheatgrass (Agropyron smithii Rydb.) transmitted WSMV at significantly lower rates than mites reared on wheat. Once these mites adapted to wheat, they transmitted WSMV at rates comparable with those of colonies that were always reared on wheat (6). More recently, Skoracka et al. (19) found multiple cryptic lineages of Aceria

Corresponding author: Camila Oliveira-Hofman, coliveirahofman@gmail.com

Accepted for publication 16 December 2014.

http://dx.doi.org/10.1094/PDIS-08-14-0868-RE

(C) 2015 The American Phytopathological Society tosichella with diverse but distinct host ranges. This shows that A. tosichella is a genetically heterogeneous species complex.

Two distinct WCM genotypes were found in Australia and named as type 1 and type 2 based on nuclear and mitochondrial DNA (5). Also, using nuclear and mitochondrial DNA, Hein et al. (10) were able to separate five mite colonies, originally isolated from collections made in South Dakota (SD), Montana (MT), Texas (TX), Kansas (KS), and Nebraska (NE), into two distinct groups that corresponded genetically to the type 1 (SD, MT, TX, and KS) and type 2 (NE) mites found in Australia (5). These two mite types also correspond to two genotypes that were collected from wheat (20). The state locations where these mites were collected are not representative of the genetic diversity present in the field. Mixed populations of type 1 and type 2 were found within fields and even within wheat heads collected in NE, KS, and MT (18). These five mite colonies (10) originated from the exact colonies used in making biotype comparisons (9) and in establishing differential transmission of WMoV by WCM (14). Thus, the type 1 and 2 mite genotypes differ in relation to biotypic and virus transmission characteristics.

While mite types can vary in their ability to transmit viruses, there is also variation within types. In the United States, both type 1 and type 2 mite genotypes were shown to transmit WSMV at varying rates (14). However, in Australia, only type 2 mites were able to transmit WSMV (13). Type 2 mites (NE colony) transmitted WSMV at an average rate of 43 to $68 \%$, depending on the vector's phenological stage (18). WMoV was transmitted by type 1 mites (KS, TX, SD, and MT colonies) at lower rates than type 2 (NE colony) mites (14). TriMV was transmitted by single type 2 mites at a rate of $41 \%$ but not by type 1 mites. However, type 1 mites transmitted TriMV at a lower rate $(2 \%)$ when allowing continuous movement of large numbers of mites from infected to uninfected plants (12).

Coinfection of wheat with WCM-transmitted viruses may affect transmission rates of individual viruses. Low WMoV transmission rates on barley increased by type 1 mites (MT colony only) when coinfected with WSMV (14). Using an unknown mite source, Seifers et al. (16) obtained their highest TriMV transmission rate $(21 \%)$ when single mites were transferred from source plants coinfected with WSMV. 
Given the increases in transmission rates for $\mathrm{WMoV}$ in the presence of WSMV and the uncertainty of transmission of TriMV from coinfected plants, a better understanding of the nature of these viral coinfections and their impact on transmission and epidemiology is needed. Because coinfection of wheat with these viruses readily occurs in nature $(2,3)$, there is a need to evaluate WSMV and TriMV transmission in the presence of other WCM-transmitted viruses. The objective of this research was to determine how coinfection of wheat by WSMV and TriMV affects individual virus transmission by the WCM. Two studies were undertaken to (i) establish whether differential transmission of TriMV and WSMV by the type 2 WCM occurred from coinfected wheat and (ii) determine whether TriMVWSMV coinfection enhanced the ability of type $1 \mathrm{WCM}$ to transmit TriMV.

\section{Materials and Methods}

Mite colony maintenance. Established aviruliferous colonies of type 1 (MT and SD) and type 2 (NE) WCM were used. Mite colonies were maintained under artificial lights (cycle of $14 \mathrm{~h}$ of light and $10 \mathrm{~h}$ of darkness) in either a growth chamber or a colony room maintained at approximately $22^{\circ} \mathrm{C}$. Colonies were maintained on 'Millennium' wheat grown in 15-cm-diameter pots by regularly (approximately every 3 weeks) transferring mites to new wheat plants. Cylindrical cages were placed over each pot to prevent contamination. These cages contained two vents on opposite sides and an open top, all covered with Nytex screen (80-micron mesh opening; BioQuip Products).

Transmission by type 2 WCM. This experiment compared the transmission of WSMV and TriMV by individual type 2 WCM from single- and coinfected wheat. Millennium wheat was seeded in 4-cmdiameter cone-tainers (Stuewe \& Sons Inc.) filled with autoclaved greenhouse soil. Plastic cylindrical cages $(5 \mathrm{~cm}$ in diameter and $50 \mathrm{~cm}$ in height) with two to three Nytex vents were used to cover the cone-tainer plants. Three source plants (replicates) for each of four treatments were inoculated with sterilized water (mock), TriMV, WSMV, or WSMV + TriMV at 21 days after seeding. Crude sap of a 1:10 (wt/vol) ratio of infected tissue in sterilized water was extracted for each virus with a mortar and pestle. For single inoculations, $10 \mathrm{ml}$ of the crude sap was combined with $10 \mathrm{ml}$ of sterilized water. For coinoculations, $10 \mathrm{ml}$ of each virus crude sap were combined. Thus, all inocula resulted in a 1:20 dilution. Plants to be inoculated were sprinkled with carborundum to allow scarring of the plant tissue and initiation of virus infection. Rub inoculation was performed by dipping the pestle in the inoculum and gently rubbing the entire length of the exposed leaves.

Within a week after inoculation, $10 \mathrm{WCM}$ were placed on a pointmount triangle (card stock material, 11-mm height by 3-mm base) and carefully placed into the leaf axil of the newest leaf on each source plant. A mite transfer tool, made from a wood dowel with a single human eyelash attached, was used for mite transfers. Plants were then placed in a growth chamber (cycle of $14 \mathrm{~h}$ of light and $10 \mathrm{~h}$ of darkness) maintained at $27^{\circ} \mathrm{C}$ for 2 weeks.

After 2 weeks, single mites were transferred from each source plant to each of ten 14-day old test plants (two- to three-leaf stage). Source plants were cut and viewed under the microscope and mites were picked up with the transfer tool. A test plant was placed on an adjacent microscope and one mite was transferred directly to the whorl of the newest leaf. Only large (adult or late nymph) mites exhibiting normal movement were transferred to test plants. Test plants were immediately covered with cages and left overnight to allow mite establishment. Test plants were then transferred to a growth chamber held at $27^{\circ} \mathrm{C}$ (cycle of $14 \mathrm{~h}$ of light and $10 \mathrm{~h}$ of darkness). After the single-mite transfers, approximately 0.15 to $0.2 \mathrm{~g}$ of plant tissue from each source plant was stored at $-20^{\circ} \mathrm{C}$ and later tested for WSMV and TriMV via double-antibody sandwich enzymelinked immunosorbent assay (DAS-ELISA). Only test plants from sources testing positive for the respective virus treatment were included in the statistical analysis.

Single-mite transfer test plants were harvested 21 to 24 days after infestation. Mite survival was determined by presence or absence for each of the test plants. At harvest, leaf pieces from test plants were sampled and stored at $-20^{\circ} \mathrm{C}$ until assayed for WSMV and TriMV via DAS-ELISA. Because of the extensive labor involved in mite transfers, the number of replicates for each run was limited to 3 ; however, this was conducted four times for a total of 12 source plants (replicates) for each treatment.

Type 1 versus type 2 transmission. The objective of this experiment was to determine whether WSMV + TriMV coinfection would influence virus transmission rates for type 1 WCM. Type 2 WCM was included as a comparison. Cone-tainer planting, inoculation procedures, and mite transfers were performed as described in the previous section. This experiment was conducted two times. The first run included three source plants each for a mock and WSMV + TriMV treatment for each of three WCM colonies tested: type 2 (NE) and type 1 (MT and SD). For the second run, the mock was eliminated to enable testing of six coinfected source plants. For each virus treatment, mites were transferred individually from each source plant to 10 separate test plants. For the mock treatment used in the first run, only five single-mite transfers were made for each source plant. Nine WSMV + TriMV coinfected source plants (90 test plants) were used for each colony, except the MT colony that only had 8 source plants (80 test plants) because one source plant tested negative for WSMV.

Test plants were harvested 21 days after single-mite transfers in the first run. Due to advanced symptom development in the second run, test plants were harvested only 14 days post WCM transfers. Plants were cut at the soil level and inspected for mite survival. Leaf tissue (approximately 0.15 to $0.2 \mathrm{~g}$ ) for each test plant was placed into a mesh bag and stored at $-20^{\circ} \mathrm{C}$ until DAS-ELISA testing for WSMV and TriMV.

Virus assay. DAS-ELISA for WSMV and TriMV was performed for all test plants. For each sample, approximately 0.15 to $0.2 \mathrm{~g}$ of plant tissue was added to a mesh bag (Agdia, Inc.). General extraction buffer (GEB) was added to the mesh bags at a 1:10 (wt/vol) ratio and then tissue was ground using a tissue homogenizer (Agdia Inc.). WSMV and TriMV tests were performed simultaneously, and leaf extract from the same mesh bag was used for both tests. ELISA plates (96-well Flat-Bottom Immuno Plate; Maxisorp, Nunc, Thermo Scientific Inc.) were coated with TriMV immunoglobulin G (IgG;24) at $100 \mu \mathrm{l} /$ well and $1: 1000(\mathrm{vol} / \mathrm{vol})$ or WSMV capture antibody (Agdia Inc.) at 1:400 (vol/vol) in carbonate buffer, and stored overnight at $4{ }^{\circ} \mathrm{C}$. The following morning, plates were rinsed three times with phosphate-buffered saline with Tween (PBST). Extract $(100 \mu \mathrm{l})$ of each sample was added to each of two wells of the WSMV- and TriMV-IgG-coated plates and incubated for $1 \mathrm{~h}$ at $37^{\circ} \mathrm{C}$. Plates were washed with $1 \times$ PBST. Rabbit anti-WSMV or TriMV IgG-ALP conjugate antibody diluted in GEB $(100 \mu \mathrm{l})$ was added to the plates at 1:400 ( $\mathrm{vol} / \mathrm{vol})$ for WSMV and 1:500 ( $\mathrm{vol} / \mathrm{vol})$ for TriMV, and incubated for $1 \mathrm{~h}$ at $37^{\circ} \mathrm{C}$. Plates were washed with $1 \times$ PBST. p-Nitrophenyl phosphate $(100 \mu \mathrm{l}$ of $1 \mathrm{mg} / \mathrm{ml})$ in $0.1 \mathrm{M}$ diethanolamine buffer, $\mathrm{pH}$ 9.8, was added to each well, and plates were incubated at room temperature in the dark for at least $1 \mathrm{~h}$. Absorbance estimates at $405 \mathrm{~nm}$ were obtained with a Multiskan FC Spectrophotometer (Thermo Scientific Inc.). A sample was considered positive if absorbance value was at least two times higher than that of negative controls (buffer and healthy extract) $(16,17)$.

Data analysis. Data were analyzed using direct comparisons of transmission rates between WSMV and WSMV + TriMV and between TriMV and WSMV + TriMV treatments. PROC GLIMMIX (SAS, v. 9.3; SAS Institute Inc.) was used, specifying a binomial distribution for WSMV and TriMV presence because a plant was either positive or negative for each virus. Type III tests of analysis of variance and least significant differences for virus presence were used to generate differences between WSMV and TriMV transmission in single- and coinfected treatments; source plants were treated as random effects. Interactions of mite survival and treatment response were also tested by including survival-treatment interaction as a response in the model statement. Separate analyses of virus presence were performed for plants with surviving mites and for plants with no surviving mites. Treatment effects and interactions at $P \leq 0.05$ 
were considered significant. Odds ratios were calculated by using PROC GLIMMIX (SAS, v. 9.3; SAS Institute Inc.) and compared the relative odds of WSMV transmission given its coinfection with TriMV, and TriMV transmission given its coinfection with WSMV.

\section{Results}

Transmission by type 2 WCM. All treatment source plants used in this study tested positive via DAS-ELISA for their respective viruses. All mock source plants and test plants tested negative for both WSMV and TriMV, indicating that no cross-contamination occurred. There was no significant treatment by run interaction, so data were combined across all four runs $\left(F_{3,320}=0.49, \operatorname{Pr}>F=0.69\right)$. The virus assay for WSMV indicated that type $2 \mathrm{WCM}$ from singleinfected source plants transmitted the virus at a 50.0\% rate (standard error $[\mathrm{SE}]=5.7, n=120$; Fig. 1 ). WCM feeding on plants coinfected with WSMV and TriMV transmitted WSMV at a rate of $35.6 \%$ (SE = 5.3, $n=120$; Fig. 1). WCM feeding on single-infected plants had a TriMV transmission rate of $43.3 \%$ ( $\mathrm{SE}=5.6, n=120$; Fig. 1$)$. Mites feeding on plants coinfected with WSMV and TriMV had a total TriMV transmission rate of $56.8 \%$ ( $\mathrm{SE}=5.6, n=120$; Fig. 1 ). Mites feeding on coinfected source plants transmitted both viruses $23 \%$ of the time, transmitted TriMV alone at a rate of $33 \%$, and transmitted WSMV alone at a reduced rate of $12.5 \%$ (Fig. 1). Transmission efficiency of WSMV was significantly reduced when TriMV was present in the source plant (50 versus 35.6\%, $P r>|t|=0.0274$; Table 1). The opposite occurred for TriMV. The rate of TriMV transmission by the WCM increased significantly when WSMV was present in the source plant (43.3 versus $56.8 \%, P r>|t|=0.0425$; Table 1). Overall, there was an odds ratio of 0.55 for WSMV transmission from

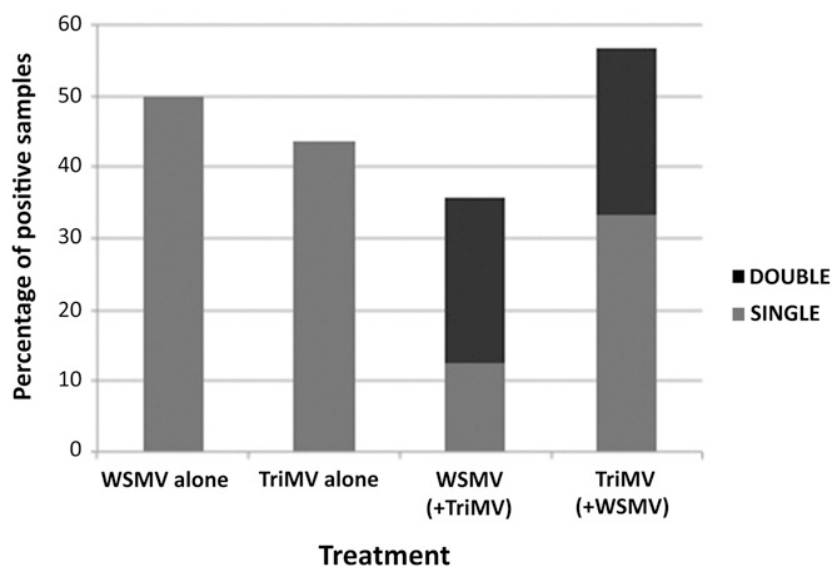

Fig. 1. Percentage of positive virus samples transmitted by type 2 wheat curl mites. WSMV = Wheat streak mosaic virus and TriMV = Triticum mosaic virus coinfected plants over single-infected plants (Table 1). The TriMV transmission odds ratio was 1.72 for coinfected compared with single-infected plants (Table 1). These odds ratios mean that mites exposed to coinfected plants have lower odds of transmitting WSMV ( 0.55 times), but higher odds of transmitting TriMV (1.72 times) when compared with mites exposed to single-infected plants.

WCM survival rates on the test plants were $65,55,40$, and $37 \%$ for WSMV, mock, TriMV, and coinfected plants, respectively. WSMV and mock survival rates did not differ significantly from one another but they were significantly higher than the TriMV and coinfected treatments. There was a significant interaction between mite survival and WSMV transmission rates $\left(F_{1,225}=4.33, \operatorname{Pr}>F=0.0386\right)$ but there was no interaction between mite survival and TriMV transmission rates $\left(F_{1,222}=0.64, \operatorname{Pr}>F=0.4235\right)$. Hence, if we restrict analysis to only those plants with surviving mites, WCM did not significantly differ in WSMV transmission rates between the WSMV single- and coinfected treatments (Table 2). If mites survived, the rate of WSMV transmission was $59.7 \%$ when mites fed on singleinfected plants and $68 \%$ when mites fed on coinfected plants $(\mathrm{Pr}>$ $|t|>0.05$, nonsignificant [NS]). If the mites did not survive to the end of the experiment, the transmission rate was $31.8 \%$ for the WSMV single-infected treatment and $16.1 \%$ for the coinfected treatment $(\operatorname{Pr}>|\mathrm{t}|>0.05$, NS).

Type 1 versus type 2 transmission. There was no colony-run interaction $\left(F_{2,254}=0.45, \operatorname{Pr}>F=0.64\right)$; therefore, virus transmission data were combined across runs. SD and MT colonies (type 1) were unable to transmit TriMV but NE (type 2) mites transmitted TriMV at a $47 \%$ rate $(\mathrm{SE}=4.6, n=90)$. NE mites transmitted WSMV at a $45.5 \%$ rate $(\mathrm{SE}=11.8, n=90)$, SD mites transmitted WSMV at a $36.5 \%$ rate (SE $=11.1, n=90)$, and MT mites transmitted WSMV at a $20.9 \%$ rate $(\mathrm{SE}=8.4, n=80)$. NE and $\mathrm{SD}$ transmission rates were not significantly different from each other but they were both significantly higher than MT transmission rate (Table 3 ). There was no significant interaction between mite survival and transmission rates of WSMV $\left(F_{2,246}=0.01, \operatorname{Pr}>|\mathrm{t}|=0.98\right)$. Mite survival in the test plants of the coinoculated treatments was $61 \%(\mathrm{SE}=5.8$ ) for SD WCM, $53 \%(\mathrm{SE}=6.2)$ for MT WCM, and $42 \%(\mathrm{SE}=5.8)$ for NE mites. SD WCM survival was significantly higher than NE WCM survival $(\operatorname{Pr}>|\mathrm{t}|=0.01)$. MT WCM survival was not statistically different than SD WCM or NE WCM $(P r>|\mathrm{t}|>0.05, \mathrm{NS})$.

\section{Discussion}

In this study, coinfection of WSMV and TriMV in the source plant was found to alter the transmission efficiency of each virus by type 2 (NE colony) WCM when compared with single virus-infected source plants. The transmission rate of TriMV when WSMV was present in source plants was significantly increased. However, WSMV had a significant reduction in transmission when source plants were coinfected with TriMV and WSMV. Type 1 mites (SD and MT colonies) did not transmit TriMV to test plants when they were reared on

Table 1. Differences of least square means for type 2 wheat curl mite (WCM) transmission from coinfected Wheat streak mosaic virus + Triticum mosaic virus (WSMV + TriMV) plants and odds ratio for each virus (single-mite transfers)

\begin{tabular}{|c|c|c|c|c|c|c|c|}
\hline Treatment & Virus present & Estimate & Standard error & df & $t$ Value & $P r>|\mathbf{t}|$ & Odds ratio \\
\hline WSMV + TriMV & WSMV & -0.59 & 0.265 & 227 & -2.22 & 0.0274 & 0.55 \\
\hline WSMV + TriMV & TriMV & 0.54 & 0.265 & 224 & 2.04 & 0.0425 & 1.72 \\
\hline
\end{tabular}

Table 2. Impact of wheat curl mite (WCM) survival post single-mite transfers on Wheat streak mosaic virus (WSMV) transmission rates

\begin{tabular}{|c|c|c|c|c|c|}
\hline Treatment $^{x}$ & WCM survival (\%) & Mite survival & WSMV transmission (\%) & Mean SEy & $t$ Groupingz \\
\hline \multirow[t]{2}{*}{ Double } & 37 & Yes & 68.3 & 6.8 & $\mathrm{a}$ \\
\hline & & No & 16.1 & 4.1 & $\mathrm{~b}$ \\
\hline \multirow[t]{2}{*}{ WSMV } & 65 & Yes & 59.7 & 5.4 & $\mathrm{a}$ \\
\hline & & No & 31.8 & 7.1 & $\mathrm{~b}$ \\
\hline
\end{tabular}

${ }^{x}$ Double treatment: wheat plants were infected with a mixed solution of WSMV and Triticum mosaic virus.

y $\mathrm{SE}=$ standard error.

${ }^{\mathrm{z}}$ For treatment least square (LS) means, LS means with the same letter are not significant at $P=0.05$. Numerator $\mathrm{df}=1$ and denominator $\mathrm{df}=225$. 
WSMV + TriMV coinfected plants. McMechan et al. (12) showed extremely low TriMV transmission rates for type 1 mites. The present study also documents that, unlike type 2 WCM, coinfection of wheat plants does not improve TriMV transmission for type 1 mites.

TriMV has been strongly associated with WSMV in the Great Plains, being detected primarily in coinfections $(2,3)$. Our study indicated that TriMV transmission efficiency increases when WSMV is present in the plant. However, only type 2 (NE) mites were able to transmit both viruses at the same time. Even though the increased TriMV transmission rate for mixed infections was modest, these findings help explain why Byamukama et al. (3) found that $91 \%$ of TriMV-positive samples were coinfected with WSMV. TriMV may be strongly associated with WSMV partly because of a fitness advantage (i.e., increased transmission rate) in the presence of WSMV.

Field surveys have shown that WSMV is the predominant WCMvectored virus, followed by $\mathrm{WMoV}$ and TriMV, the last two not always in this order (2,3). A high rate of TriMV infections occurred in coinfection with WSMV, with 76\% (2) and 91\% (3) of TriMV infections occurring with WSMV. TriMV can also co-occur with WMoV (2). Other studies have focused on effects of WSMV presence on transmission of WMoV or TriMV. Type 1 (MT) mites increased transmission of WMoV if they were already viruliferous for WSMV (14), and an unknown mite genotype transmitted TriMV primarily in association with WSMV (16). However, the present study is the first to show that TriMV hinders WSMV transmission. Specifically, this study demonstrated that WCM transmission of WSMV is negatively affected by TriMV presence. Lower WSMV transmission for coinfected plants may be related to reduced mite survival. WCM survival on coinfected plants was significantly reduced when compared with mite survival on WSMV-infected plants and the mock treatment in the first experiment. The second experiment was not set up to compare mite survival on coinfected plants with mite survival on healthy plants but survival rates for the three mite sources varied, with significant differences between SD and NE mites. NE mite survival on coinfected test plants in experiment 2 was similar to the previous experiment (42 versus 37\%). Previous work has shown that type 1 and type 2 mites reared on TriMV-infected wheat had lower survival and reproductive rates (11) and that type 2 WCM feeding on WSMVinfected plants had enhanced reproductive rates (18). Given that type 1 and type 2 populations coexist in the field, it is likely that these transmission and mite survival interactions influence the transmission and epidemiology in the field. These effects need to be further investigated in the field.

The exact mechanisms of the interactions between WSMV and TriMV in terms of transmission rates are not known. One explanation for the increase in TriMV transmission might be that coinfection with TriMV and WSMV increases the concentration of both viruses in susceptible cultivars, as demonstrated by Tatineni et al. (23), thus making the virus more readily available for mite acquisition. Titer appears to be dependent on how long the plants have been infected. In coinfections, WSMV concentration decreased at 28 days postinoculation (dpi), when compared with single-infected plants, but TriMV concentration in coinfected plants remained higher than in singleinfected plants (23). Stenger et al. (22) found a similar pattern in the coinfection of corn with WSMV and Maize chlorotic mottle virus (MCMV). Titers of both viruses were higher in coinfected plants at

Table 3. Wheat streak mosaic virus transmission in coinfected plants by type 1 (South Dakota [SD] and Montana [MT]) and type 2 (Nebraska [NE]) wheat curl mites (WCM)

\begin{tabular}{lcccc}
\hline Colony & $\begin{array}{c}\text { Positive } \\
\text { samples/total }\end{array}$ & $\begin{array}{c}\text { Mean } \\
\text { transmission (\%) }\end{array}$ & Mean SE & $\boldsymbol{t}$ Grouping $^{\mathbf{z}}$ \\
\hline $\mathrm{NE}$ & $44 / 90$ & 45.5 & 11.8 & $\mathrm{a}$ \\
$\mathrm{SD}$ & $36 / 90$ & 36.5 & 11.1 & $\mathrm{a}$ \\
MT & $20 / 80$ & 20.9 & 8.4 & $\mathrm{~b}$ \\
\hline
\end{tabular}

${ }^{\mathrm{z}}$ For treatment least square (LS) means, LS means with the same letter are not significant at $P=0.05$. Numerator $\mathrm{df}=2$ and denominator $\mathrm{df}=256$.
15 to 17 dpi. However, WSMV titers in coinfected plants decreased at 28 to $30 \mathrm{dpi}$ and were comparable with single-infected WSMV plants. At 28 to $30 \mathrm{dpi}$, MCMV concentration in coinfected plants remained higher than in single-infected plants (22). In this study, WCM fed on the source plants for about 2 weeks and, at the time of single-mite transfers, each source plant had been infected for at least 16 or 21 days. WSMV titer may have been decreasing in concentration in coinfected plants by the time mites were transferred to test plants. But WSMV is retained through molting, so it is also plausible that any given mite used for transmission acquired the virus prior to titers decreasing.

An increase in TriMV transmission was found along with reduced WSMV transmission rates using type 2 WCM. This suggests not only that WSMV enhances TriMV transmission by type 2 WCM but also that TriMV interferes with WSMV transmission. The differences in transmission, $14.3 \%$ decrease in WSMV transmission in coinfected plants and $13.5 \%$ increase in transmission of TriMV, were statistically significant but were not drastic increases and should be interpreted with caution. In these experiments, we are only making inferences about the interaction of WSMV and TriMV on singlemite transmission.

Future studies should investigate the mechanisms involved in the increase of TriMV transmission rate and the decrease in WSMV transmission rate when WCM are fed on coinfected source plants. Even though type $1 \mathrm{WCM}$ does not transmit TriMV, it is necessary to know whether coinfection of wheat with WSMV and TriMV can reduce WSMV transmission rates by the type 1 mite. More in-depth research needs to be done to determine the implications of these findings and determine whether coinfection by WSMV and TriMV affects vector capabilities and mite biology under field conditions.

\section{Acknowledgments}

We thank E. Byamukama and J. McMechan for their outstanding assistance in this project. Funding for this work was provided by the Agriculture and Food Research Initiative Competitive Grants Program Grant Number 2010-85605-20546 from the National Institute of Food and Agriculture.

\section{Literature Cited}

1. Appel, J. A., De Wolf, E., Bockus, W. W., and Bowden, R. L. 2013. Preliminary 2013 Kansas wheat disease loss estimates. Online publication. Kansas Coop. Plant Dis. Surv. Rep. http://agriculture.ks.gov/docs/default-source/ pp-disease-reports-2012/2013-ks-wheat-disease-loss-estimates44D2D289EE71. pdf?sfvrsn $=6$

2. Burrows, M., Franc, G., Rush, C., Blunt, T., Ito, D., Kinzer, K., Olson, J., O'Mara, J., Price, J., Tande, C., Ziems, A., and Stack, J. 2009. Occurrence of viruses in wheat in the Great Plains region, 2008. Online publication. Plant Health Prog.

3. Byamukama, E., Seifers, D. L., Hein, G. L., De Wolf, E., Tisserat, N. A., Langham, M. A. C., Osborne, L. E., Timmerman, A., and Wegulo, S. N. 2013. Occurrence and distribution of Triticum mosaic virus in the Central Great Plains. Plant Dis. 97:21-29.

4. Byamukama, E., Wegulo, S. N., Tatineni, S., Hein, G. L., Graybosch, R. A., Baenziger, P. S., and French, R. 2014. Quantification of yield loss caused by Triticum mosaic virus and Wheat streak mosaic virus in winter wheat under field conditions. Plant Dis. 98:127-133.

5. Carew, M., Schiffer, M., Umina, P., Weeks, A., and Hoffmann, A. 2009. Molecular markers indicate that the wheat curl mite, Aceria tosichella Keifer, may represent a species complex in Australia. Bull. Entomol. Res. 99:479-486.

6. del Rosario, M. S., and Sill, W. H., Jr. 1965. Physiological strains of Aceria tulipae and their relationships to the transmission of wheat streak mosaic virus. Phytopathology 55:1168-1175.

7. Harvey, T. L., Martin, T. J., and Seifers, D. L. 1995b. Survival of five wheat curl mite, Aceria tosichella Keifer (Acari: Eriophyidae), strains on mite resistant wheat. Exp. Appl. Acarol. 19:459-463.

8. Harvey, T. L., Martin, T. J., Seifers, D. L., and Sloderbeck, P. E. 1997. Change in virulence of wheat curl mite detection on TAM 107 wheat. Crop Sci. 37: 624-625.

9. Harvey, T. L., Seifers, D. L., and Martin, T. J. 1999. Survival of wheat curl mites on different sources of resistance in wheat. Crop Sci. 39:1887-1889.

10. Hein, G. L., French, R., Siriwetwiwat, B., and Amrine, J. W. 2012. Genetic characterization of North American populations of the wheat curl mite and dry bulb mite. J. Econ. Entomol. 105:1801-1808.

11. McMechan, A. J. 2012. Transmission of Triticum mosaic virus and its impact on the biology of the wheat curl mite Aceria tosichella Keifer (Eriophyidae), and an evaluation of management tactics for the wheat curl mite and the wheatmite-virus complex. M.S. diss., University of Nebraska-Lincoln. 
12. McMechan, A. J., Tatineni, S., French, R., and Hein, G. L. 2014. Differential transmission of Triticum mosaic virus by wheat curl mite populations collected in the Great Plains. Plant Dis. 98:806-810.

13. Schiffer, M., Umina, P., Carew, M., Hoffmann, A., Rodoni, B., and Miller, A. 2009. The distribution of wheat curl mite (Aceria tosichella) lineages in Australia and their potential to transmit wheat streak mosaic virus. Ann. Appl. Biol. 155:371-379.

14. Seifers, D. L., Harvey, T. L., Louie, R., Gordon, D. T., and Martin, T. J. 2002. Differential transmission of isolates of the High Plains virus by different sources of wheat curl mites. Plant Dis. 86:138-142.

15. Seifers, D. L., Harvey, T. L., Martin, T. J., and Jensen, S. G. 1997. Identification of the wheat curl mite as the vector of the High Plains virus of corn and wheat. Plant Dis. 81:1161-1166.

16. Seifers, D. L., Martin, T. J., Harvey, T. L., Fellers, J. P., and Michaud, J. P. 2009. Identification of the wheat curl mite as the vector of Triticum mosaic virus. Plant Dis. 93:25-29.

17. Seifers, D. L., Martin, T. J., Harvey, T. L., Fellers, J. P., Stack, J. P., RybaWhite, M., Haber, S., Krokhin, O., Spicer, V., Lovat, N., Yamchuk, A., and Standing, K. G. 2008. Triticum mosaic virus: A new virus isolated from wheat in Kansas. Plant Dis. 92:808-817.

18. Siriwetwiwat, B. 2006. Interactions between the wheat curl mite, Aceria tosichella Keifer (Eriophyidae), and wheat streak mosaic virus, and distribution of wheat curl mite biotypes in the field. Ph.D. diss., University of Nebraska, Lincoln.

19. Skoracka, A., Kuczynski, L., Szydlo, W., and Rector, B. 2013. The wheat curl mite Aceria tosichella (Acari: Eriophyoidea) is a complex of cryptic lineages with divergent host ranges: evidence from molecular and plant bioassay data. Biol. J. Linn. Soc. 109:165-180.

20. Skoracka, A., Rector, B., Kuczyński, L., Szydło, W., Hein, G., and French, R. 2014. Global spread of wheat curl mite by its most polyphagous and pestiferous lineages. Ann. Appl. Biol. 165:222-235.

21. Slykhuis, J. T. 1955. Aceria tulipae Keifer (Acarina: Eriophyidae) in relation to the spread of wheat streak mosaic. Phytopathology 45:116-128.

22. Stenger, D. C., Young, B. A., Qu, F., Morris, T. J., and French, R. 2007. Wheat streak mosaic virus lacking helper component-proteinase is competent to produce disease synergism in co infections with Maize chlorotic mottle virus. Phytopathology 97:1213-1221.

23. Tatineni, S., Graybosch, R. A., Hein, G. L., Wegulo, S. N., and French, R. 2010. Wheat cultivar-specific disease synergism and alteration of virus accumulation during co- infection with Wheat streak mosaic virus and Triticum mosaic virus. Phytopathology 100:230-238.

24. Tatineni, S., Sarath, G., Seifers, D. L., and French, R. 2013. Immunodetection of Triticum mosaic virus by DAS- and DAC-ELISA using antibodies produced against coat protein expressed in Escherichia coli: potential for high-throughput diagnostic methods. J. Virol. Methods 189:196-203.

25. Tatineni, S., Ziems, A. D., Wegulo, S. N., and French, R. 2009. Triticum mosaic virus: a distinct member of the family Potyviridae with an unusually long leader sequence. Phytopathology 99:943-950.

26. Velandia, M., Rejesus, R. M., Jones, D. C., Price, J. A., Workneh, F., and Rush, C. M. 2010. Economic impact of Wheat streak mosaic virus in the Texas High Plains. Crop Prot. 29:699-703. 